\title{
Post Endolaryngeal Laser Surgery Carbon Granuloma
}

\section{Endolarengeal Lazer Cerrahisi Sonrası Karbon Granülomu}

\author{
Burak Ertaş, İsmet Emrah Emre, Elif Aksoy, Arif Ulubil, Melih Güven Güvenç, Hasan Tanyeri, \\ Ömer Faruk Ünal*
}

Acıbadem University Faculty of Medicine, Department of Otorhinolaryngology, Istanbul, Turkey

${ }^{*}$ Koç University Faculty of Medicine, Department of Otorhinolaryngology, Istanbul, Turkey

\section{Abstract}

Aim: This study was performed to highlight the phenomenon of carbon granulation formation after laser vocal cord surgery. Emphasis was put on the fact that these granulomas closely resemble tumor recurrence and due to the similarity of appearance, histological evaluation is necessary for diagnosis.

Methods: This study included 35 male patients presenting to the Acıbadem University Hospital with early-stage laryngeal cancer between 2009 and 2013. All patients underwent laser-assisted interventions on the vocal cords. Patient follow-up was continued for two years and granuloma formation or tumor recurrence was noted.

Results: During the two-year follow-up period, a total of five patients presented with new vocal cord lesions. One of the cases was determined to be a tumor recurrence. The remaining four were carbon granulomas that regressed during the follow-up period.

Conclusion: Although carbon granuloma formation is not very common, it is still frequent enough to be thoroughly discussed in the literature. With laser surgery for early-stage laryngeal cancer becoming more popular every day, the incidence of carbon granulomas is likely to increase. An algorithm for this type of lesion without putting patients' health at risk will be a valuable tool in the near future.

Keywords: Carbon granuloma, endolaryngeal laser, cordectomy, laryngeal cancer
Öz

Amaç: Bu çalışma vokal kord lazer cerrahisinden sonra karbon granülom oluşumunu vurgulamak için yapılmıştır. Bu granülomların görünümü tümör nüksü ile benzerlik gösterdiği için, ayrımında histolojik değerlendirmenin gerekliliği ele alınmıştır.

Yöntemler: Çalışmaya 2009-2013 yılları arasında Acıbadem Maslak Hastanesi'ne başvuran erken evre glottik kanserli 35 erkek hasta alındı. Tüm hastaların vokal kordlarına lazer yardımlı girişim uygulandı. Hastalar iki yıl süreyle takip edildi ve granülom oluşumu veya tümör nüksü varlığı kaydedildi.

Bulgular: Iki yıllık izlem sürecinde beş hastada yeni oluşan vokal kord lezyonu saptandı. Bunlardan birinin tümör nüksü olduğu belirlendi. Diğer dört olgudaki lezyonlar ise takip sürecinde gerileyen ve kaybolan karbon granülomları idi.

Sonuç: Karbon granülom oluşumu çok yaygın olmasa da literatürde ele alınacak kadar sıktır. Erken evre glottik kanser tedavisinde lazer cerrahisi her geçen gün daha popüler hale gelmektedir ve karbon granülomlarının insidansının artması muhtemeldir. Bu tip bir algoritma risk altındaki hastaların tedavi yönetiminde yakın gelecekte değerli bir araç olacaktır.

Anahtar Sözcükler: Karbon granülomu, endolarengeal lazer, kordektomi, larenks kanseri

\section{Introduction}

Laryngeal carcinoma constitutes $0.8 \%$ of all new cancer cases seen in the United States (US). It is the 20th most common malignancy in the US. The prevalence of laryngeal carcinoma in men is approximately five times higher than in women. In the US, laryngeal carcinoma constitutes $0.6 \%$ of deaths due to cancer. The average occurrence age is 65 (1). Histopathologically, squamous cell carcinomas (SCC) constitute more than $95 \%$ of cases $(2,3)$. If we are to analyze the locations of where laryngeal carcinoma originates from; 30-35\% are supraglottic, 60$65 \%$ are glottic and $1-5 \%$ are subglottic (2).

The treatment options for $\mathrm{T} 1$ glottic tumors are surgery and radiotherapy. Surgical treatment offers the options of laryngofissure cordectomy and endolaryngeal cordectomy.
Address for Correspondence/Yazışma Adresi: Burak Ertaş

Acıbadem University Faculty of Medicine, Department of Otorhinolaryngology, İstanbul, Turkey Phone: +90 2123044937 E-mail: drbertas@yahoo.com

Received/Geliş Tarihi: 11 August 2016 Accepted/Kabul Tarihi: 04 Semtember 2016
- Copyright 2017 by The Medical Bulletin of University of Health Sciences Haseki Training and Research Hospital The Medical Bulletin of Haseki published by Galenos Yayinevi. ${ }^{\circledR}$ Telif Hakkı 2017 Sağlkk Bilimleri Üniversitesi Haseki Eğtim ve Araştırma Hastanesi Haseki Tip Bülteni, Galenos Yaynevi tarafindan basılmıştri. 
Endolaryngeal cordectomy can be performed via two different techniques: classical microlaryngeal surgery (cold instrumentation) and endolaryngeal laser surgery (hot instrumentation) (4).

The use of endolaryngeal lasers in laryngeal cancer treatment was first reported in 1972 by Strong and Jako (5). Endolaryngeal laser cordectomy can be performed for dysplastic lesions of the vocal cords, vocal cord malignancies and bilateral abductor paralysis indications (6).

Endolaryngeal cordectomies were classified in the year 2000 by the European Laryngological Society as; Type I (subepithelial cordectomy), Type II (subligamentous cordectomy), Type III (transmuscular cordectomy), Type IV (total cordectomy), Type Va (extended cordectomies encompassing the contralateral cord), Type $\mathrm{Vb}$ (extended cordectomies encompassing the arytenoid), Type Vc (extended cordectomies encompassing the ventricular band), and Type $\mathrm{Vd}$ (extended cordectomies encompassing the subglottis) (7). The Type VI cordectomy (extended cordectomies encompassing the anterior commissure) was added to the above classification in 2007 (8).

The advantages of endolaryngeal laser cordectomies are shorter operating times, shorter length of hospital stay, less bleeding throughout the operation, less post-op edema, non-necessity of tracheostomy, a larger area of vaporization than border mucosa and no deterioration to the larynx's stability $(3,9)$. However, potential difficulties in observing the endolaryngeal imaging, the possible misleading of the secondary effects of necrosis on the thermal laser pathology limit evaluation; inability to continuously perform block resections and, if necessary precautions are not taken, the risk of harm to the patient and operating room staff are the disadvantages of endolaryngeal laser cordectomies $(3,10)$.

In our study, we intend to discuss and highlight carbon granulomas - lesions that can be confused with recurrence of a tumor - detected in the follow-ups of our patients who underwent endolaryngeal laser cordectomies.

\section{Methods}

In this study, we evaluated patients who were admitted to our clinic between the years of 2009 and 2013 and underwent endolaryngeal laser surgery due to early-stage glottic laryngeal carcinomas. Ethics committee approval was received for this study from the ethics committee of Acıbadem University (2016-3/7). Written informed consent was obtained from patients who participated in this study.

The endolaryngeal cordectomies performed on our patients were conducted under apneic anesthesia, in the micro-laryngeal surgical position, with a $\mathrm{CO}_{2}$ laser powered at four watts used in the super-pulse and continuous mode (AcuPulse 30/40 ST CO 2 laser; Lumenis, Yokneam, Israil ).

In order to increase resection visibility (to better assess the ventricular base) partial excision was performed on the ventricular band of the side of that was operated on. After the resection, frozen section biopsies were taken and the operation was terminated depending on the results of the surgical margin control findings. Thirty-five patients were included in our study. Of these 35 (100\%) patients, all were male. The patients" average age was recorded as 59 years (38-86). According to the stages of tumors among the patients, $33(94 \%)$ cases were categorized as stage T1aNOM0 and two (6\%) cases were categorized as stage T1bN0M0 tumors.

The analysis on the types of endolaryngeal surgery performed on patients were as follows: in $16(45.7 \%)$ cases Type III cordectomies, in another $16(45.7 \%)$ cases Type IV cordectomies, in $2(5.7 \%)$ cases Type $\mathrm{VI}$ cordectomies and in one $(2.9 \%)$ case a Type Vc cordectomy was noted. In this series of 35 cases, 19 (54\%) patients underwent right side excisions, 14 (40\%) left side excisions and two patients (6\%) underwent double-sided excisions.

The postoperative pathology results of the cases showed that $15(43 \%)$ cases had well-differentiated squamous epithelial cell carcinoma, 18 (51\%) - moderately differentiated squamous cell carcinoma and two (6\%) had poorly differentiated squamous epithelial cell carcinoma. In all patients, the margins were reported as tumor free.

During the postoperative period, all patients were administrated $1500 \mathrm{mg} /$ day oral dose of azithromycin for three days, $1600 \mathrm{mg}$ daily oral dose of $\mathrm{N}$-acetyl cysteine for one week, and Lansoprazole $2 \times 30 \mathrm{mg} /$ day for at least one month. Additionally, throughout the postoperative period, the patients continued to use a proton pump inhibitor until the epithelialization of the surgical field was completed. All the patients were discharged within 24 hours postoperatively. None of the patients underwent a tracheotomy and none experienced postoperative bleeding. Furthermore, none of the patients required early re-operative measures or any re-excisions after surgery. None of the patients were given any additional oncological treatment (radiotherapy and/or chemotherapy) after their primary surgeries.

Patient follow-ups were conducted at monthly intervals for the first year and every three months after a two-year period.

\section{Statistical Analysis}

The study was conducted without using any biostatistical test. We only used percentage calculations of the results. We presented percentage values of our findings. 


\section{Results}

In one $(2.9 \%)$ of the cases, a postoperative recurrence was observed during the first year of follow-up. This case had undergone a type VI cordectomy and had a tumor involving both cords. No invasion of the cartilage was observed on the preoperative computed tomography of the larynx. The period that the recurrence was determined during the postoperative follow-up showed that the lesion was located at the front commissure and showed subglottic extension. The patient was offered a total laryngectomy and elective neck dissection, however the patient opted for radiochemotherapy.

Of our 35 endolaryngeal laser cordectomy cases, four (11.4\%) patients, during the postoperative $3^{\text {rd }}$ to $6^{\text {th }}$ month of the follow-up presented with lesions 2-3 mm in diameter with spherical appearance in the surgical field which completely disappeared at the end of the 1 st postoperative year.

Case 1: The patient had a highly differentiated SCC and a Type III cordectomy was performed. A 2-3 mm evenly contoured lesion was identified on the operated vocal cord during the $3^{\text {rd }}$ postoperative month. A biopsy was taken via direct laryngoscopy. The postoperative pathology results showed acute inflammatory granulation tissue and reactive epithelial changes. Eight months after the first operation, the lesion completely regressed and the surgical field was fully epithelialized (Figure1, 2).

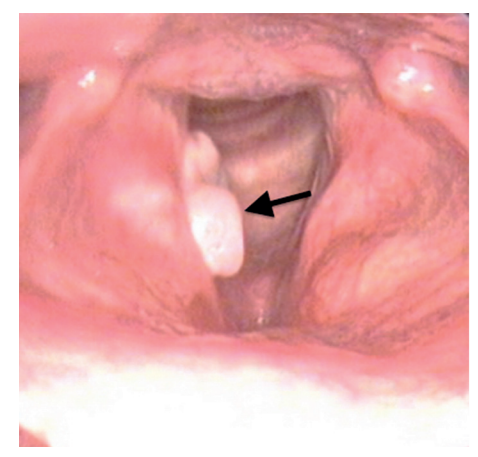

Figure 1A. Post-operative $3^{\text {rd }}$ month imaging, arrow: Carbon granuloma

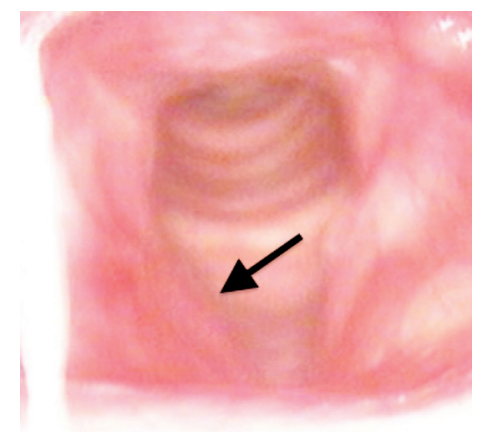

Figure 1B. Post-operative $8^{\text {th }}$ month imaging, arrow: Fully epithelized surgical area
Case 2: The patient had a moderately differentiated SCC and a Type IV cordectomy was performed. A $2 \mathrm{~mm}$ evenly contoured lesion was identified in the center of the operated vocal cord level during the $2^{\text {nd }}$ postoperative month. The follow-up of the patient was conducted at two-week intervals. No additional surgery was performed. Three months postoperatively, the lesion completely regressed and the surgical field was fully epithelialized (Figure 3).

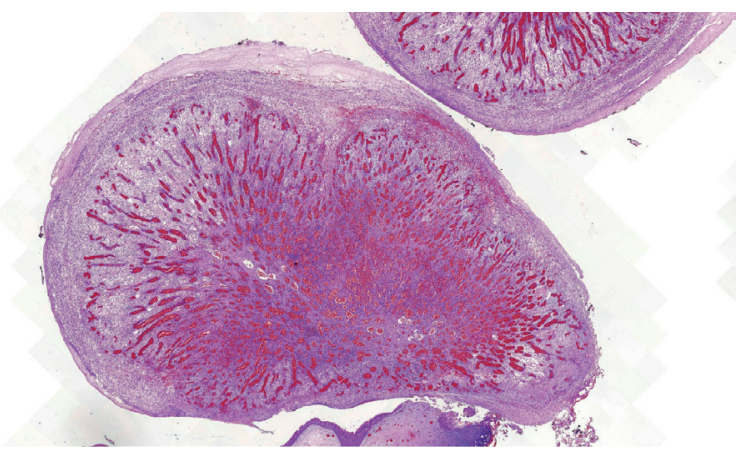

Figure 2. Image of carbon granuloma pathology taken due to suspicion of a recurrence in Case 1

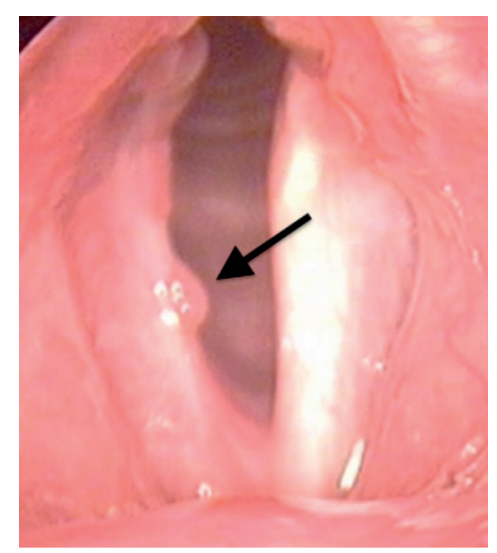

Figure $\mathbf{3 A}$. Post-operative $2^{\text {nd }}$ month image, arrow: Carbon granuloma

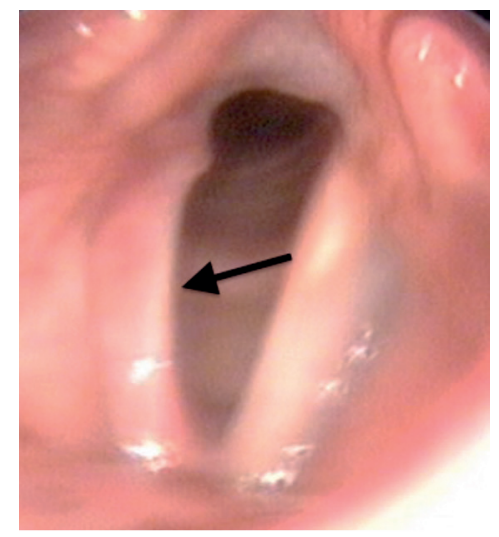

Figure 3B. Post-operative $3^{\text {rd }}$ month image, arrow: Fully epithelized surgical area 
Case 3: The patient had a poorly differentiated SCC and a Type VI cordectomy was performed. A 2-3 mm evenly contoured lesion was identified in the posterior $1 / 3$ of the operated vocal cord during the $6^{\text {th }}$ postoperative month.

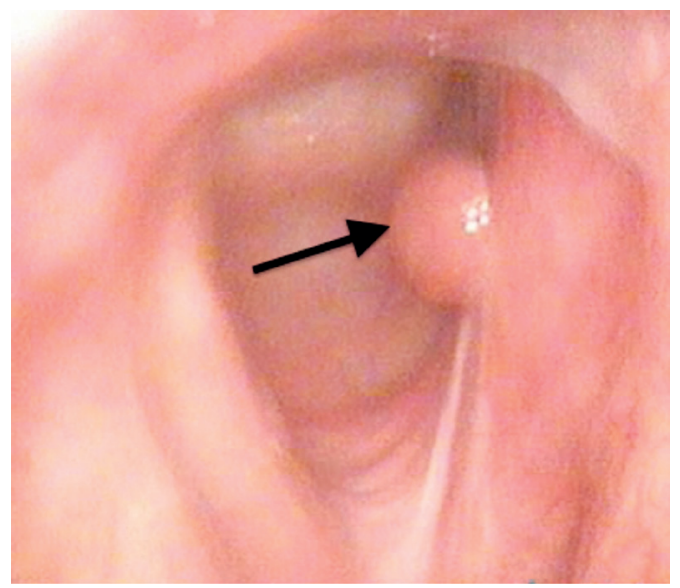

Figure 4A. Post-operative $6^{\text {th }}$ month image, arrow: Carbon granuloma

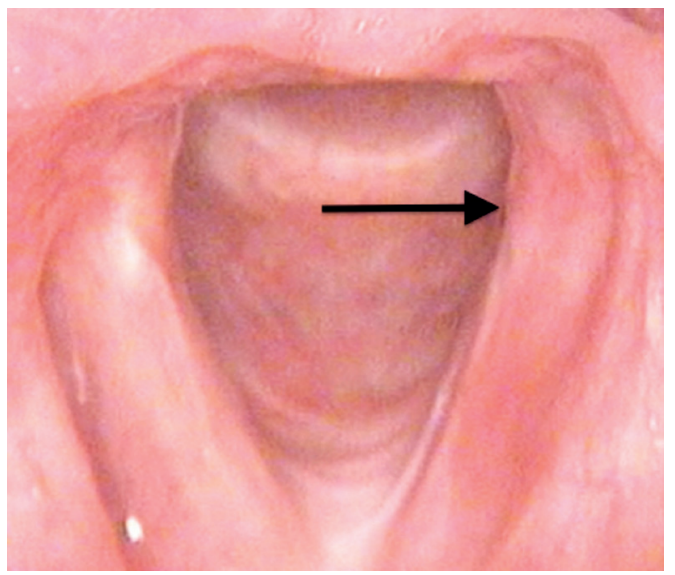

Figure 4B. Post-operative $12^{\text {th }}$ month image, arrow: Fully epithelized surgical area

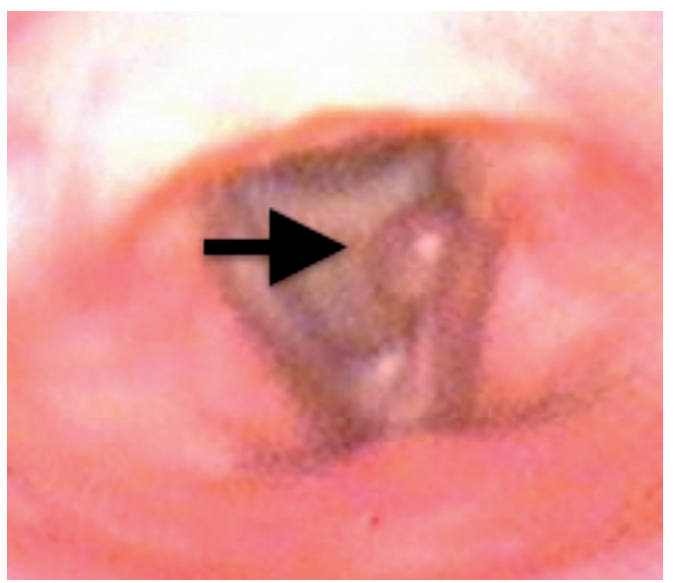

Figure 5. Case 4. Post-operative $4^{\text {th }}$ month image, arrow: Carbon granuloma
The follow-up of the patient was conducted at two-week intervals. No additional surgery was performed. Twelve months postoperatively, the lesion completely regressed and the surgical field was fully epithelialized (Figure 4).

Case 4: The patient had a moderately differentiated SCC and a Type IV cordectomy was performed. A 2-3 mm evenly contoured lesion was identified in the posterior of the operated vocal cord level during the $4^{\text {th }}$ postoperative month. The follow-up of the patient was conducted at two-week intervals. No additional surgery was performed. Eight months postoperatively, the lesion completely regressed and the surgical field was fully epithelialized (Figure 5).

\section{Discussion}

Throughout the last years, endolaryngeal laser surgery has led to changes in surgical technique selections in the treatment of glottic laryngeal carcinoma. In comparison to open technique approaches, the advantages of this technique for patients include less postoperative bleeding, shorter hospital stay, and no deterioration of the larynx stability, while disadvantages can be healing issues observed in the postoperative surgical field and the misleading effect of thermal necrosis in determining the boundaries of pathology specimens $(3,9,10)$.

In our study, we aimed to emphasize laser carbon granulomas in cases where patients have undergone endolaryngeal laser cordectomies due to early-stage glottic larynx carcinoma. Our study was aimed at clarifying these laser carbon granulomas, which we found to be a defect in healing during the postoperative period, with seemingly tumor recurrences.

Within the surgical excision field, the irregular healing of surgical wounds throughout the early phase can be misleading. Caused by the thermal effects of the laser, spherically structured carbon granulomas during the healing phase can be confused with tumor recurrences.

Betlejewski et al. (11) first described laser carbon granulomas in an article published in Polish in 2005. In their study of 167 cases of SCC of the larynx in which laser cordectomies were applied, Betlejewski et al. (11) found 3-5 mm spherical, evenly contoured granulomas in the central area in 14 patients (8.4\%) during 1-6-month follow-up.

In our series, the diameter of the spherical, evenly contoured lesions found in $4(11.4 \%)$ of the 35 patients was 2-3 $\mathrm{mm}$. Three lesions were located in the rear zone and one in the central zone.

Of the four patients in which laser carbon granulomas were detected, three patients had a type IV cordectomy (75\%), 1 had a type III cordectomy (25\%). 
The fact that laser carbon granulomas were detected more frequently in type IV cordectomies suggests that the contact between the cartilage and laser increases the probability of lesion formation.

\section{Conclusion}

The follow-up of patients who underwent laser cordectomies concluded that; within the first six months, in the presence of relatively ordered spherical lesions, the possibility of laser granulomas can be considered and therefore may not be a recurrence, thus, not necessitate biopsy. However, as the patients carry a risk of recurrence they must be carefully monitored (by two week intervals) and observation that the lesion has completely disappeared must be conclusive.

\section{Ethics}

Ethics Committee Approval: Ethics committee approval was received for this study from the ethics committee of Acibadem University (2016-3/7).

Informed Consent: Written informed consent was obtained from patients who participated in this study.

Peer-review: Internally peer-reviewed.

\section{Authorship Contributions}

Surgical and Medical Practices: Ö.F.Ü. Concept: Ö.Fü., B.E., H.T. Design: Ö.F.Ü., B.E. Data Collection or Processing: I.E.E., A.U. Analysis or Interpretation: M.G.G., E.A. Literature Search: B.E., I.E.E. Writing: B.E.

Conflict of Interest: No conflict of interest was declared by the authors.

Financial Disclosure: The authors declared that this study received no financial support.

\section{References}

1. Siegel R, Ma J, Zou Z, Jemal A. Cancer statistics, 2014. CA Cancer J Clin 2014;64:9-29.
2. Rosai J. Larynx and trachea. In: Rosai J, editor. Surgical Pathology. 9th ed. Edinburg London Newyork; 2004. p. 30558.

3. Hoffman HT, Iseli TA, Karnell LH, et al. Cummings CW. Otolaryngology Head and Neck Surgery, fifth edition Mosby Book St Louis: 2010. p.1512-39.

4. Silver CE, Beitler JJ, Shaha AR, Rinaldo A, Ferlito A. Current trends in initial management of laryngeal cancer: the declining use of open surgery. Eur Arch Otorhinolaryngol 2009;266:1333-52.

5. Strong MS, Jako GJ. Laser surgery in the larynx. Early clinical experience with continuous $\mathrm{CO} 2$ laser. Ann Otol Rhinol Laryngol 1972;81:791-8.

6. Spiegel JR, Sataloff RT. Surgery for carcinoma of the larynx. In: Gould WJ, Sataloff RT, Spiegel JR, editors: Voice Surgery. St. Louis: Mosby; 1993. p. 307-37.

7. Remacle M, Eckel HE, Antonelli A, et al. Endoscopic cordectomy. A proposal for a classification by the Working Committee, European Laryngological Society. Eur Arch Otorhinolaryngol 2000;257:227-31.

8. Remacle M, Van Haverbeke C, Eckel H, et al. Proposal for revision of the European Laryngological Society classification of endoscopic cordectomies. Eur Arch Otorhinolaryngol 2007;264:499-504.

9. Canis M, Ihler F, Martin A, Matthias C, Steiner W. Transoral laser microsurgery for T1a glottic cancer: Review of 404 cases. Head Neck 2015;37:889-95.

10. Makki FM, Rigby MH, Bullock M, et al. $\mathrm{CO}(2)$ laser versus cold steel margin analysis following endoscopic excision of glottic cancer. J Otolaryngol Head Neck Surg. J Otolaryngol Head Neck Surg 2014;43:6.

11. Betlejewski S, Sinkiewicz A, Mackiewicz H, Owczarek A, Dalke K. Carbon granuloma-an unwanted effect of laryngeal laser microsurgery. Pol Merkur Lekarski 2005;19:417-9. 